The Philosophical Journal of Conflict and Violence

Vol. I, Issue 2/2017

(C) The Authors, 2017

Available online at http://trivent-publishing.eu/

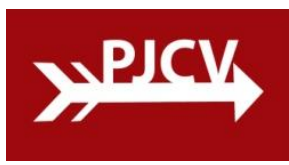

\title{
Tomelleri, Stefano. Ressentiment: Reflections on Mimetic Desire and Society
}

East Lansing: Michigan State University Press, 2015. 246 pp.

Nietzsche, Scheler, Girard. These three names form the central pillar of Stefano Tomelleri's 2015 book, Ressentiment: Reflections on Mimetic Desire and Society. Tomelleri writes from the perspective of René Girard's mimetic theory, the book being part of the "Breakthroughs in Mimetic Theory" series. It is, in essence, an attempt to bring back some of the core ideas of the German philosophers Friedrich Nietzsche and Max Scheler from the dusty past into the $21^{\text {st }}$ century by refurbishing them through mimetic theory. Furthermore, Tomelleri attempts to sketch the guidelines of a sociology of ressentiment, as a way to analyse present-day society.

Anyone who is unfamiliar with the philosophical concept of ressentiment has to be careful to distinguish it from the more common English word "resentment." While resentment can be seen as a feeling of bitterness, indignation, and an ensuing desire for vengeance, ressentiment is the inability to express such feelings, e.g. the inability to take revenge on those deemed responsible for feelings of resentment. In short, ressentiment can be understood as "frustrated resentment."

Mimetic theory, as first devised by the French anthropologist René Girard, aims to explain human desire through mimesis. Explained simply, we learn by imitating others - we see this from a very basic level, such as children who learn by imitating their parents. Mimetic theory, however, takes this principle of learning through imitation much further and claims that our very desire is a result of imitation. We desire what others desire, in the form of a blind instinct. Mimetic desire also explains the origins of conflict: as we imitate each other's desires, we are doomed to strive for the very same objects of desire. Given the finitude of such objects, conflict arises. So, what stops society from collapsing under continuous conflicts over the common objects of desire? Girard tells us that by designating a scapegoat, for example a person or a group of people, and uniting against that scapegoat, a perpetual conflict is averted. The community is saved, but violence remains in the form of scapegoating. For Girard, Christianity distinguishes itself in a special way from other religions in that it views things from the perspective of the innocent victims, instead of the persecutors' perspective, as in ancient myths and religions. In this way, Christianity deconstructed the scapegoat mechanism of these myths and religions.

Tomelleri starts from the Nietzschean idea of ressentiment. Nietzsche makes a distinction between "slave" and "master" morality. These moralities correspond to what Gilles

This is an Open Access article distributed in accordance with the Creative Commons Attribution Non Commercial (CC-BY-NC-ND 4.0) license, which permits others to copy or share the article, provided original work is properly cited and that this is not done for commercial purposes. Users may not remix, transform, or build upon the material and may not distribute the modified material (bttp:// creativecommons.org/licenses/by-nc/4.0/) 
Deleuze calls "active" and "reactive" forces. Master morality is characterized by its active nature. It creates values, it decides what is good or bad. Slaves, however, are fated to a reactive morality. They perceive the masters as those who prevent them from fulfilling their desires (an expression of ressentiment) and therefore define their good and bad values in opposition to the masters' values: what master morality considers to be good, slave mentality perceives as bad. For Nietzsche, Christianity is inseparable from ressentiment. Its very conception was an act of ressentiment from the weak and downtrodden masses to bring down their "nobler" masters. Nietzschean ressentiment is characterized by a severe aversion to Christian morality. Equality and solidarity are signs of a weak culture that has lost its vitality. They are values venerated by slaves. However, Tomelleri also stresses the creative power present in the Nietzschean ressentiment: it apparently has the ability to reshape our lives, our values, our thinking patterns.

Max Scheler's notion of ressentiment follows Nietzsche's for the most part. Unlike Nietzsche however, he does not go on a crusade against Christianity. Ressentiment surely exists, but it is found in bourgeois morality. It originates in the perpetual comparisons we make with others, from which the nobler people are exempt. If nothing else, the first part of the book is an excellent explanation of ressentiment, worth reading for anyone wishing to familiarize with this idea. Tomelleri writes comprehensively, conveying important and sometimes difficult philosophical concepts with clarity, without compromising their depth or complexity.

Both Nietzsche and Scheler believe ressentiment is something individual, a private emotion. Even though Scheler proposes a sociological analysis of ressentiment as a pathology, he does not go all the way in forming a relational conception of it. Scheler believes the origin of ressentiment is the comparison with the other and the feeling of inadequacy this induces. When social factors obstruct us from relieving ourselves from such negative feelings, ressentiment can be dubbed a pathology. Despite incorporating the role of social factors into his theory, the feeling of ressentiment itself remains something individual. This is where Tomelleri comes in.

Although Nietzsche and Scheler have a somewhat different view of ressentiment, according to Tomelleri, they are united in their opinion that ressentiment is something essential. It necessarily belongs to a certain group of people: the slaves for Nietzsche, the bourgeois for Scheler. Tomelleri makes the remark that ressentiment need not be restricted to these groups, that "nobles" for instance can be subject to ressentiment as well. Despite using such a risky word as 'essential' (which reeks of Platonism and disregards the nuances in the works of Nietzsche and Scheler), Tomelleri has a good point here, we are finite and fragile beings, being resentful now and then seems inevitable. Additionally, as Tomelleri argues, ressentiment is a creative force which can shape social order, as it can lead to mass movements that seek to radically alter the existing order of things, e.g. through political parties.

The Nietzschean and Schelerian concepts of ressentiment are thus subsequently interpreted from Girard's perspective of mimetic theory. Ressentiment is explained as resulting from mimetic desire. The fact that others want what we want prevents us from attaining it, resulting in cropped up feelings of revenge, i.e. ressentiment. Ressentiment can then be understood not as an individual phenomenon, as Nietzsche and Scheler do, but a 
Book Review

Tomelleri, Stefano. Ressentiment: Reflections on Mimetic Desire and Society

sociological one. This is perhaps the most important point Tomelleri makes. Investigating ressentiment through the magnifying glass of mimetic theory shows the relational character of ressentiment. Furthermore, understanding the relational character of ressentiment results in understanding a significant part of the origin of violence in our present-day world. As Nietzsche and Girard already claimed, our modern institutions are largely built on foundations of ressentiment. For example, our judicial system tends to favour the victims, i.e. the weak, by protecting them through a set of universal rights. The result is a revitalization of ressentiment as a tool for societal analysis, a vital part in Tomelleri's quest for a sociology of ressentiment.

The main example used in the book in order to illustrate this analysis is that of the Lega Nord, a right-wing, separatist political party in Italy. The analysis itself is well-founded, describing the rise and the fall of the "Northern League" in terms of ressentiment. Tomelleri's claim is that this political party exploits the discrepancy in possessed wealth between the elite (the governing classes) and the masses by fuelling the feeling of ressentiment in the masses. However, Tomelleri's choice for this specific example is somewhat arbitrary. While this concrete example aids to clarify how ressentiment functions in society, it does not add much to the preceding and following parts of the book. For those not familiar with Italian politics, the choice for this specific example remains unclear.

Still, the outlook of a sociology of ressentiment is significant. In an age of extreme violence, the need to investigate the causes and inner development of conflict is evident. Gathering a diagnosis of modern institutions in terms of ressentiment and an analysis on the origins of desire, as Tomelleri does, may allow us to do just that.

This book is a wonderful marriage between the Nietzschean and Schelerian notions of ressentiment, and Girard's mimetic theory. The child of this marriage, a relational sociology of ressentiment, is just taking its first steps, but is promising. At a basic level, this book answers the question: "What does ressentiment mean in the context of mimetic theory?" It is worth reading for this reason alone. However, the more ambitious goal of the book is to set rough guidelines for a sociology of (relational) ressentiment. Does it succeed in doing this? Given the relative short length of the book, it does so remarkably well, providing a ground for further works to germinate in. Because of the short length, do not expect this book to have the final say on the subject. Nor a final say on what the first steps towards a relational view of ressentiment should be. Some important questions go unanswered. For example, Tomelleri is quick to appeal to solidarity and fraternity as a cure to the poisoning effect of ressentiment, but fails to consider alternatives. Are solidarity and fraternity really the only antidote to ressentiment? What other avenues might be explored as possible cures to this societal ail? Furthermore, the book gives an outline of how a sociology of ressentiment might work, but does not really give any concrete guidelines. Therefore, it remains the first toe-dipping in the swimming pool of relational ressentiment. This being said, for anyone interested in a fresh view on ressentiment, and a mimetic analysis of contemporary society, Stefano Tomelleri's book is a necessary read.

Burak Demirbas 